\title{
Estimating a Fiscal Reaction Function for Nigeria
}

\section{Patricks Ogiji ${ }^{1}$ and Kayode J. Ajayi ${ }^{2}$}

The study examines the determinants of fiscal balance and the impact of the selected macroeconomic variables on the primary balance of government. It aims to estimate the fiscal reaction function for Nigeria and determine whether the implementation of fiscal policy is sustainable in the long-run. A Fiscal Reaction model was developed and ARDL technique was used to establish the relationships and interactions among the variables. The study investigated whether the fiscal measures pursued by the government from 2000:Q1 to 2018:Q4 was adequate in addressing the accumulation of huge debt. The analysis of the stylized facts reveals that the government had continued to run budget deficits for almost the entire period, except for a few period. The public debt to GDP, which is a major determinant of the primary balance, is negative and significant implying that a fiscal rule that encourages a strong reduction in debt-to-GDP levels would result in substantial pressure for Nigeria to run large primary surpluses in the future. The CUSUM and CUSUMSQ tests show the recursive residual plots of the fiscal reaction function are within the 5 per cent critical lines, hence, providing evidence of stable fiscal reaction function for Nigeria. The study thus, recommends that, apart from the urgent need for the fiscal authorities to adopt urgent reforms to discourage huge debt accumulation, improve revenue generation capacity and more fundamentally, expenditure switching to improve the quality of expenditure, the transition from primary deficits to primary surpluses should follow a gradual process.

Keywords: Fiscal Reaction Function; ARDL Model; Debt; Revenue

JEL Classification: E62, H62, H63, H39

DOI: $10.33429 /$ Cjas.11120.2/5

\section{Introduction}

The purpose and pursuit of sound fiscal policy is to impact and direct the performance of an economy in order to achieve macroeconomic stability, income redistribution, reallocation of resources through sustained growth as well as promoting an enabling environment for investors. Based on its fundamental objectives, fiscal policy adjustments can be achieved through various channels like adjustments in expenditure of government; changes in levels of government tax revenue, amongst others. Such impacts are transmitted through changes

\footnotetext{
${ }^{1}$ Corresponding Author: pogiji@cbn.gov.ng.

2 The authors are staff of Monetary Policy Department, Central Bank of Nigeria.

The views expressed in this paper are those of the authors and do not necessarily represent those of the Central Bank of Nigeria.
} 
in the fiscal budget.

Nigeria's debt stock dates to the pre-independence era with the first Nigeria's external borrowing in 1964 from the Paris Club of Creditor Nations. From that time, Nigeria's external debt had generally risen significantly. The country's borrowing after 1970s increased significantly as government acquired loans for development and reconstruction projects after the civil war. The period 1986 to 1992 marked the period of Nigeria's earliest debt rescheduling and strategy for debt reduction. Nigeria's domestic debt stock position in 2000 stood at N833.38 billion rising from the N84.09 billion recorded in 1990. External debt also rose significantly from N298.61 billion to a high of N3,097.38 billion, in the same period (DMO, 2018).

Prior to the exit from the Paris club in 2005, Nigeria's total external debt as at 2005 stood at about N2,695.07 billion, it however dropped significantly to N451.46 billion in 2006 as both domestic and external debt declined significantly after the exit but continued to pile up years after. The domestic stock started to grow much more than the external debt in view of the recourse to domestic borrowing. Thus, by the end-December of 2017, the domestic debt had risen to about N18.38 trillion (exclusion of State debt) from the N898.25 billion recorded at end-2000. The total public debt as at end-December 2017, however, was N21,725,773.03 million (DMO 2018). In addition, the significant increase in Nigeria's debt stock was mainly attributed to additional issuances for the funding of the annual budget deficits and refinancing of matured debt securities. Low revenue accretion and increased government spending induced rise in the fiscal deficit.

Thus, notwithstanding the 2004/2005 Paris Club debt exit in which the Country had \$18 billion (or 60 percent) of the $\$ 30$ billion owed to the cartel written off, and the favorable global macroeconomic environment afterwards, the country's debt profile continues to soar. This development is however, confronted with rising budget deficit stemming from growing population, declining oil revenue, low tax revenues and rising costs of government commitments in infrastructural development.

There are models of fiscal sustainability that argued that countries that are highly indebted could reduce or stabilize the debt built-up by generating future primary surpluses. For instance, the study by Oronde et al. (2019) for a sample of 53 developing countries, found a 
positive and significant response in the primary balance to changes in the lagged GDP ratio, implying that there were deliberate efforts by the fiscal authorities to ensure overall macroeconomic stability. Thus, a country with high fiscal deficit is under obligation to minimize the deficit or possibly achieve a surplus by increasing its revenue and/or reducing expenditure.

The debt condition became more entrenched particularly after the 2008/2009 global financial crisis and five years later in 2014, when the price of crude petroleum products declined sharply. Inspite the commitments of the Federal Government of Nigeria (FGN) in ensuring fiscal consolidation and sustainability, the challenge remains intractable as fiscal performance seems to be strongly affected by fluctuations in oil prices. It is therefore natural to expect within a broad spectrum, conflict in policy goals, in terms of stabilizing debt and output. Hence, it is crucial that fiscal policy remain pro-active to guide future borrowing plans and minimize the risk of fiscal insolvency.

The Fiscal Reaction Function (FRF) has increasingly become an important tool for assessing the fiscal policy stance in an economy. The FRF is a rule or condition derived from budget constraint of government. It can be used to establish how fiscal policy responds to business cycles. The fiscal reaction function is used as guide to verify whether government reacts to changes in primary balance arising from debt procurements. it analyzes the relationship between primary balance and debt stock. The FRF signals how sound and sustainable fiscal policy stances are, and where appropriate responses should be channeled.

Against this background, the paper investigates how the Nigerian government responds to changes in its debt levels, thereby showing the kind of deliberate fiscal adjustments embarked upon overtime to achieve sustainability. The rest of the paper is structured as follows: Section 2 reviews relevant theoretical and empirical literature on fiscal reaction function. Section 3 discusses the data and methodology, while Section 4 provides the empirical results and analysis. Section 5 concludes the paper.

\section{Literature Review}

\subsection{Theoretical Literature}

The desire of every government is to achieve a fiscal policy that is sustainable. In practice, whenever government runs fiscal operations where revenue comes short of projected expenditure, the government considers bridging the gap between revenue and expenditure (deficit); 
by borrowing domestically or externally. Interest payments on borrowed funds (debt service), government revenue, exchange rate, inflation rate amongst others are variables that imposes constraint on government primary balance positions. The identity is: net issuance of debt $=$ interest payments - primary balance (-deficit/+surplus). The net issuance of debt is total receipts from the issuance new debt excluding any amortization payments made in the period. Thus, from the evidences gleaned from the literature, the Fiscal Reaction Function (FRF), could serve the following uses: to investigate the fiscal consolidation path set out by the fiscal authorities in their budgetary planning and implementation process; to project or estimate the determinants of the primary balance such as: interest rate, output gap, debt/GDP (a key measure of fiscal sustainability); to allow the authorities to be able to set the rules for achieving targeted debt levels in the future ; to serve as basis for probabilistic debt modeling and forecasting and estimate the probable changes to the ratio - a key measure of fiscal sustainability; and, to project the future path of the country's debt by picking exogenous values for growth and interest rates.

From the foregoing, Bohn $(1995,2007)$ established that the fiscal authorities react or respond to increasing debt burden by estimating a Fiscal Reaction Function (FRF). The FRF would provide the basis for ascertaining how primary balance/GDP would respond to changes in the one-period lagged public debt/GDP, while holding other variables constant. Estimating the FRF will help fiscal authorities to access how previous and new government borrowings would impact on the economy in future (t).

The process for achieving this is an error correction mechanism. Against the backdrop that the authorities are exposed to some budget constraints, an increase in the ratio of public debt/GDP, implies that there is debt accumulation. The necessary course of action is for the government to reverse the rising trend by ensuring that it maintains a positive primary balance (Bohn 1998, 2007; Gali and Perotti 2003; De Mello 2005). The fiscal policy stance of government is constrained by some factors such as revenue, debt levels, interest on Bond etc (Burger et al., 2011). In simplified terms, the government budgetary constraint can be written in the manner of Mutuku (2015):

$$
D_{t}=D_{t-1}+\left(1+i_{t}\right) D_{t-1}-p B_{t}
$$

where, D: Public debt stock; i: Nominal interest rate on government bonds; pB: Primary balance (+ surplus; - deficit). 
According to Bohn (1998), the fiscal reaction function is derived from equation (1) and expressed as:

$$
b_{t}=\alpha+\beta d_{t}+\beta Z_{t}+U_{t}
$$

Where ' $\beta$ ' is approximately measures the presence of the internal debt correction term. The term $\mathrm{Z}$ represents vector of other variables that can also determine government primary balance such as output gap, interest rate, exchange rate, inflation rate.

The primary fiscal balance is another metric that is closely tied to the fiscal reaction function. They are usually described in forms of proportion or ratio of the GDP. On the back of theory, the primary balance of government is the difference between fiscal or budget deficits minus interest payment. It can be explained as: the government fiscal balance excluding interest payments which are equated as: Overall Fiscal Deficit is equal to (Primary Deficit) plus (Government Interest Payments). Debt service payments (interest/principal payments) is imperative in primary balance determination and represents a component of the budget. The primary balance is the target for policy intervention whenever the fiscal authorities want to achieve fiscal sustainability. It depends on the fiscal measures deployed by the fiscal policy makers. The objective of government is to achieve low fiscal deficit or primary surplus that would guarantee fiscal sustainability. The primary fiscal balance can be influenced by a spectrum of variables chiefly amongst which are, revenue, accumulated debt stock, and interest payments. In other words, the debt stock plays an analytical role to determine a country's primary balance position.

\subsection{Review of Empirical Literature}

The objective of fiscal policy in an economy is to correct macroeconomic instability; it aims to foster growth in the economy, redistribute income and invariably reduce inequality. There are empirical evidences to support the argument on the existence of several different channels through which fiscal policy promotes economic growth and development. Therefore, the use of fiscal policy as a major tool for stabilization is paramount in most less developed countries (LDCs). Government policy affect revenue receipts and expenditure and thus provide a measure of government's net receipts, its surplus or deficit. Fiscal policy serves as the government's shock absorber in specific areas of development as the government may decide to counterbalance variations that are in private consumption and investment using counter 
cyclical revenue and expenditure measures.

Most studies on fiscal reaction functions are basically empirical in nature; however, this section focuses on the different fiscal reaction functions of countries subject to constraints faced by such economies. A fiscal reaction function (FRF) determines the way government reacts to increase in debt i.e. change in debt levels. We use the FRF to establish government reactions to debt burden; estimating how lagged public debt/GDP ratio has changed the primary balance (Bohn 2007).

In establishing how various governments reacts to its debt burden and high interest payments on debt in their economies, we consider the works of Burger et al. (2011) who examined the reaction function for South Africa to changes in its debt position by employing Ordinary Least Squares (OLS), Vector autoregression (VAR), Threshold Autoregressive (TAR), Generalized Method of Moments (GMM), and Vector Error Correction Model (VECM). They established that, the country enjoyed stable fiscal policy since 1946, by manipulating the primary balance (deficit or surplus) in response to its rising debt levels. Similarly, Ganyaupfu (2014) study on South Africa provided evidence that during1990-2013 period, the country operated fiscal policy measures that were adjudged to be sustainable by making remarkable adjustments to primary balance in response to changes in its debt positions. In the same manner, Mutuku (2015) estimated the fiscal reaction functions (FRFs) for some selected European countries and tested for a change in fiscal behavior from the beginning of financial crisis. They observed that most European Union (EU) countries adjusted their fiscal policy in response to rising levels of public debt.

Mello (2007) investigated fiscal performance in Brazil and found that all levels of government react strongly to changes in indebtedness by adjusting their primary budget surplus target. He estimated fiscal reaction functions for different levels of government using monthly data from1995-2004. On re-affirming the fiscal sustainability hypothesis postulating that countries that are highly indebted needs to reduce or stabilize their current debt to achieve primary surpluses. Oronde et al (2019) used panel data for 53 developing countries and found evidence of positive relationship between debt levels and primary surplus. There was evidence that, the authorities deploy the same proportion of fiscal adjustments around public revenue and expenditure. 
Afonso and Jalles (2011) estimated fiscal responses for OECD using cross sectional panel data, and a VAR analysis. The study established that most governments increased their primary balances when faced with higher government indebtedness, while primary balances improved because of reduced government debt. In their study of the dynamics of fiscal sustainability in the eleven Euro countries. Afonso and Jalles (2015) used eleven Euro-area countries as samples, and found that, fiscal policy was sustainable in Belgium, France, Germany and Netherlands implying the presence of a Ricardian (monetary dominant) regime. Other conclusions that emerged from the study include the following; that an innovation in the budget surplus in half of the sample resulted in a negative response from debt; the 2008-2009 global crisis wielded a huge negative impact on fiscal sustainability; and thirdly, expenditure-based fiscal rules are strong determinants of fiscal sustainability.

Checherita-Westphal and Ždarek (2017) estimated a fiscal reaction function using a dynamic panel technique for countries in the euro area. The study found evidence of positive reactions of primary surpluses to higher debt over the reviewed period. Weichenrieder and Zimmer (2014) for instance, examined the fiscal reaction functions for a select group of euro-area countries under the Maastricht Treaty, to determine whether members respond to shocks arising from high level of indebtedness before and after signing the Maastricht Treaty. They observed that member countries significantly experienced reduced responsiveness in the periods after the Maastricht Treaty as compared to the prior periods.

In considering the fiscal policy responsiveness in a highly indebted country, Stoica and Leonte (2011) considered the responsiveness of Greece by estimating a Fiscal Reaction to determine the influence of public debt and GDP fluctuations on primary balances. Using the fiscal reaction function approach and quarterly data covering the period 2001Q1-2008Q2, the study established that fiscal policy is mainly driven by inertia and the impact of public debt on fiscal policy was insignificant implying that the application of wrong fiscal policy measures affected Greece economy negatively.

Another important factor in debt accumulation is Interest rates. High interest rates increase the rates at which debt stock accumulates. The study by Nguyen (2013) estimated a fiscal reaction function for India and found that its fiscal policy stance depended on the debt level, interest rate and output gap levels. The introduction of interest rate variable alongside debt and output gap in the FRF is novel and significant. In examining fiscal sustainability in a 
developing country like Ghana, Asiama, et.al. (2014) used the FRF estimation to examine how the country reacted to rising public debt accumulation. Their findings showed that the stance of fiscal policy is consistent with the inter-temporal budget constraint. Mutuku (2015) ascertained an FRF for Kenya using VAR and VECM on annual data from1970-2013 and observed that fiscal authorities reacted non-systematically to increasing debt, while, acknowledging that elections cycles affected fiscal sustainability.

For resource rich countries, particularly oil exporters, the impact of commodity price volatility on public revenue should be a major consideration in determining fiscal sustainability. The study by Baunsgaard (2003) lend support to this argument as it found that Nigeria's past fiscal policy is not sustainable because revenue and expenditure levels are influenced by oil price volatility. In determining the responsiveness of government to increasing debt accumulation, Adeosun and Adedokun (2019) used cointegration approach to estimate the fiscal reaction function for Nigeria and found a negative response of government primary balances to changes in public debt in the long run. Otonne a Oyenuga (2019) investigated the sustainability of the Nigerian government's debt in the aftermath of the Paris club exit also using co-integration analysis. Their study showed that the country's fiscal policy was not sustainable.

Other studies on Nigeria include the work by Oyekele and Ajilore (2014) who investigated whether government violated inter-temporal government budget constraint. Using ECM on data spanning over the period 1980-2010, revealed that the country's fiscal policy was weakly sustainable, while recommending increased government revenue generation as a way out. Owolabi and Dauda (2017) used an ARDL cointegrating model to examine fiscal sustainability in Nigeria for the period 1961 to 2013. The Bai-Perron multiple break point tests evident a structural shift in variables in 1981 which accounted for unsustainable fiscal deficit throughout the period. It found that fiscal deficit before 1981 was weakly sustainable but became sustainable thereafter. Similarly, Okoye et al. (2019) adopted ARDL model to determine the variables that influence fiscal deficits in Nigeria. They used data from 1981 and 2017 and established that, inflation, oil revenue, and lagged exchange rate affects fiscal deficits. There is also evidence that external debt and current exchange rate decrease the level of fiscal deficits. Ariyo (1993) examined the sustainability of fiscal policy in Nigeria from 1970 to 1990, using Present Value Constraint (PVC)/econometric approach. He concluded 
that the policy of fiscal deficit was not sustainable, as it was induced by post-civil war reconstruction efforts causing hike in deficit which continued over a longer period.

The paper contributes to the literature in several important ways. First, whereas most studies examine the response of primary balance to changes in the debt ratio, we extend the analysis to examine the response of ratio of primary balance/GDP to the output gap. To guide policy, an accurate measure of the output gap should be the basis for fiscal revenue forecast as any deviation from this, could aggravate uncertainties around fiscal outcomes in the medium to long-term. Secondly, whereas, several studies examine the fiscal reaction function, none to the best of our knowledge has examined how other components determine the primary balance for Nigeria. We dimensioned these components to include revenue/GDP, CPI and interest rate and explored how they affect the primary balance.

\subsection{Some Stylize Facts on the Variables}

\subsubsection{Fiscal Developments in Nigeria}

Attempts by the Nigerian government to maximize the benefits of sound fiscal policy include several programmes/project and public sector reforms like the Fiscal Responsibility Act, fiscal consolidation through reduction in recurrent expenditure, greater transparency in the conduct of government's fiscal operations and so many other ways that have curbed expenses on overheads. Nonetheless, government spending over the years has continued to increase and remain higher than the revenue projections, thus expanding the budget deficit. Thus, in an attempt to gain understanding on the factors which influence fiscal developments in Nigeria, we provide in this section, some stylized facts on the fiscal variables considered in the study for the period 2000Q1-2018Q4.

\subsubsection{Fiscal Operations}

Figure 1 shows periods when fiscal operations of government resulted into a budget surplus in 2001 - 2004, it, however, recorded fiscal deficit throughout the review period, until 2017 when a budget surplus was recorded. Government's fiscal operations during most of the period under review resulted in huge budget deficits and this has continued to widen due to revenue short falls and increased government spending. The oil sector remains the main stay of the Nigerian economy, providing about 80 per cent of its revenue receipt and foreign earnings. Evidence shows that, Nigeria's revenue has a positive correlation with global movement in oil prices. This is because of the mono-product structure of the economy, Consequently, 
revenue to government decline during periods of falling oil prices.

Government expenditure grew from N175,270 million in 2000Q1 to about N600,450.20 million in 2005Q1, representing about 242.10 per cent increase. It stood at N1,458,400 million in 2010Q4. The trend has remained as government expenditures continue to increase (See Figure 1b).

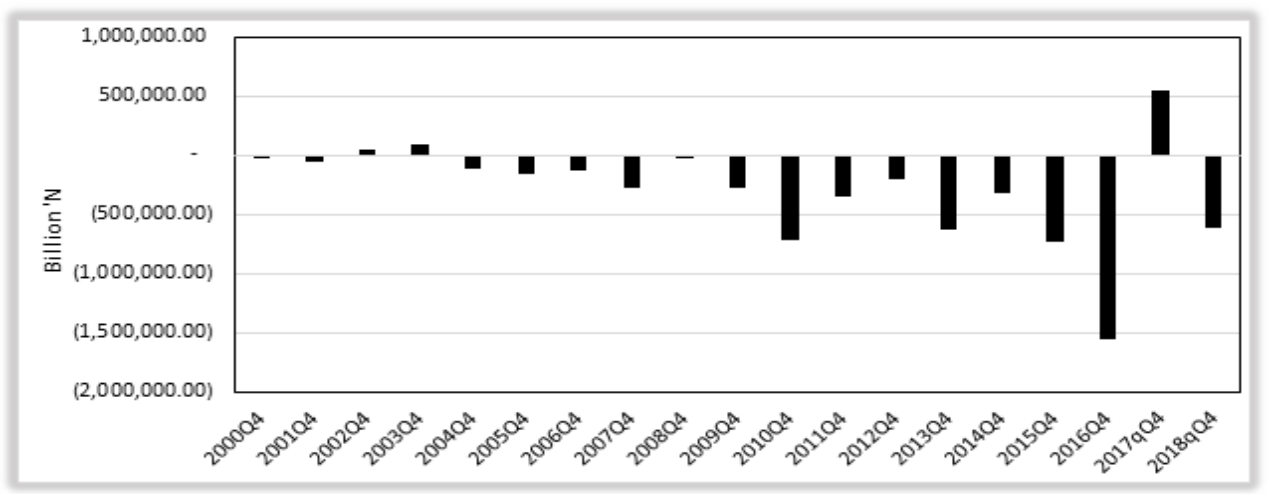

Figure 1a: Trend in Fiscal Balance (Deficit/Surplus)

Source: Office of the Accountant General of the Federation (OAGF)

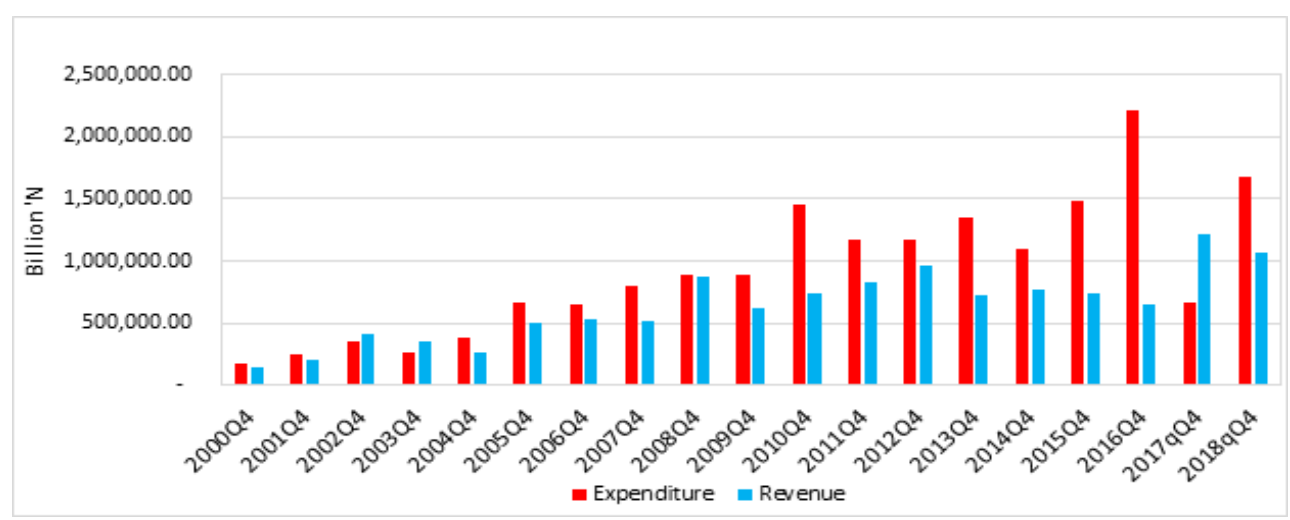

Figure1b: Trend in Fiscal Operations (Revenue \& Expenditure)

\subsubsection{Ratio of Lagged Revenue and Expenditure to GDP}

We observed consistent gap between lagged revenue and expenditure relative to GDP (Rev/GDP and Exp/GDP) for most period of the study. Except in 2017Q4 when revenue ratio to GDP was above expenditure ratio to GDP. Expenditure was consistently above revenue, indicating fiscal or primary deficit. The proportion of lagged government expenditure to GDP rose to a peak of about 18.00 per cent in 2003Q2. Lagged government revenue as a proportion of 
the GDP also rose to about 10.00 percent in the same period. Nevertheless, both variables experienced lower trend in recent times due to lower oil prices.

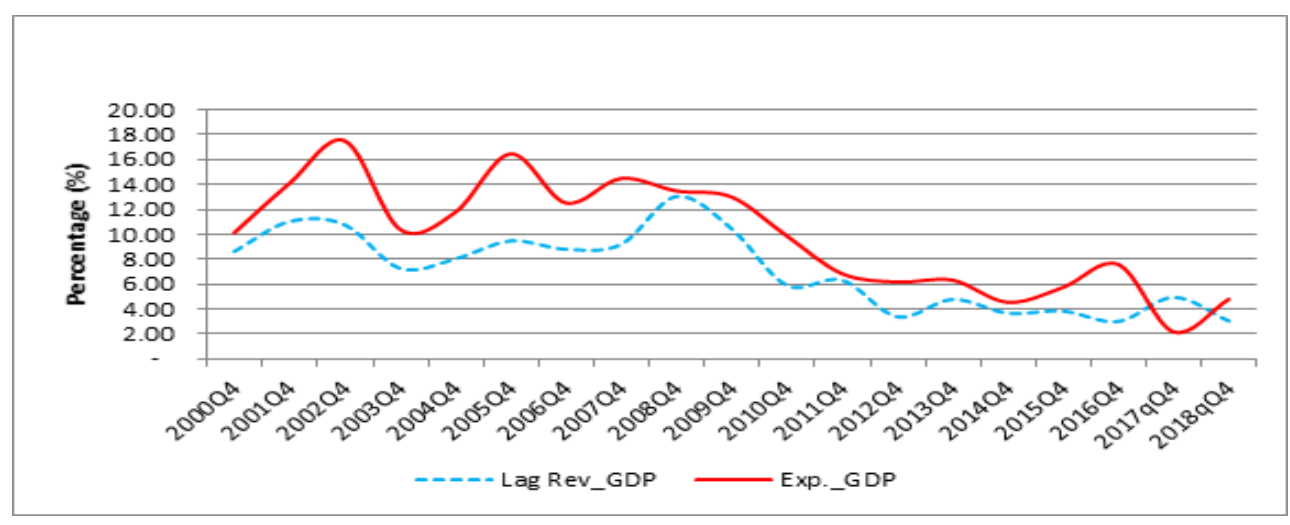

Figure 2: Ratio of Revenue and Expenditure to GDP

Source: Author's Computation

\subsubsection{Debt to GDP Ratio}

The debt-to-GDP ratio plays a significant role in fiscal consolidation and in setting prudential limits on public borrowing. Prior to 2005, the ratio of debt to GDP has been very high (over 40 percent) due to the high levels of government domestic and external indebtedness. The debt forgiveness accorded to Nigeria between 2005 and 2006 from the Parsi club of nations has help the country experienced a downwards trends in its debt to GDP ratio.

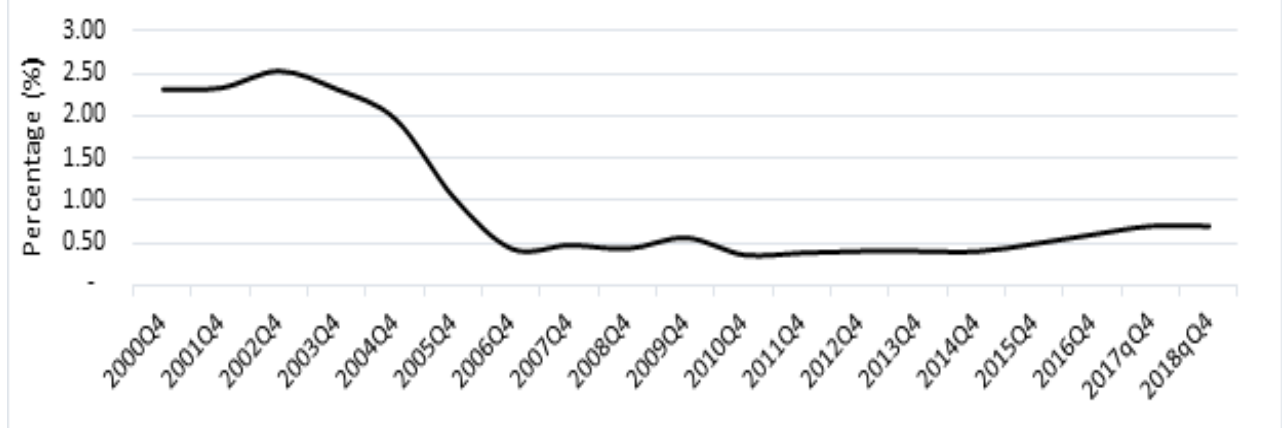

Figure 3: Trend in Nigeria Debt to GDP Ratio Source: Debt Management Office (2018)

Rising government debt and deficit ratios have negative effect in the long-term fiscal sustainability of economy. 


\subsubsection{Nigeria's Primary Balance}

The primary balance has been on the negative (fiscal deficit) over the years under review, except for 2017, which trended towards positive (fiscal surplus). This was as a result of increased government revenue in the period. The dip recorded between 2015 and 2016 was attributed to decline in oil revenue which was occasioned by economic recession.

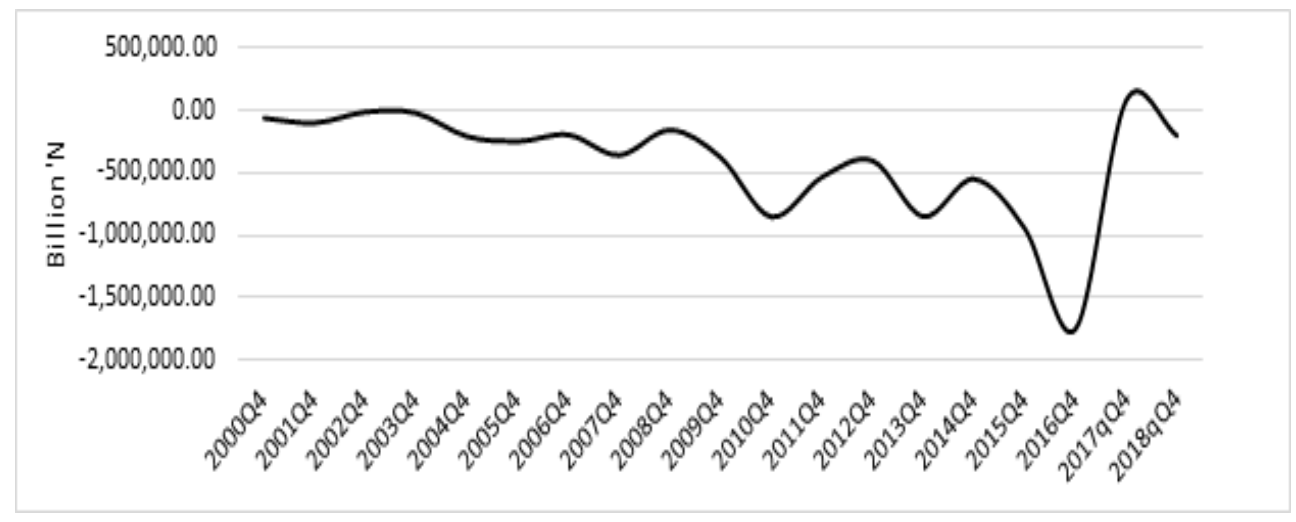

Figure 4: Nigeria's Primary Balance

Source: Author's Computation

\subsubsection{Fiscal Stance and Output Gap}

A major role of fiscal policy in both the long and short run according to Halland and Bleaney (2009a and 2009b), is to ensure macroeconomic stability. i.e. stabilizing economic performance by ensuring that the output gap is minimized in both the short run and in the long run. Thus, the output gap analysis is very appropriate especially for an economy where a cyclically adjusted target has been adopted to guide fiscal operations. We computed the output gap using the time series filtering methodology of HP filter - Hodrick-Prescott (1997) and with further guidance from Hodrick (2020) (Figure 5). A negative output gap as shown in the Figure 5 indicates that the economy is operating below its potential thus leading to high primary deficit. The counter-cyclical policy when output gap is negative should be expansionary and tightening stance when gap is positive (primary surplus). On the other hand, a positive output gap suggests that the economy is operating above its potential and this could heat up the economy.

From the output gap (Figure 5) the country experienced periods of down swings especially during the global financial crisis (2007-2009). The economy, however, recorded positive output growth (2010-2015), but later dipped into recession in 2016. The downturn of the 
economy was attributed to international oil prices that plummeted from above US\$110.00 per barrel in 2014 to as low as US\$30.00. The slow growth performance since 2016 indicates the existence of spare capacity in the Nigerian economy. Thus, to guide policy, fiscal revenue forecast should be based on accurate output gap measures. This is because any uncertainty about the size of the output gap without doubt, can lead to significant uncertainty around fiscal outcomes in the medium to long-term.

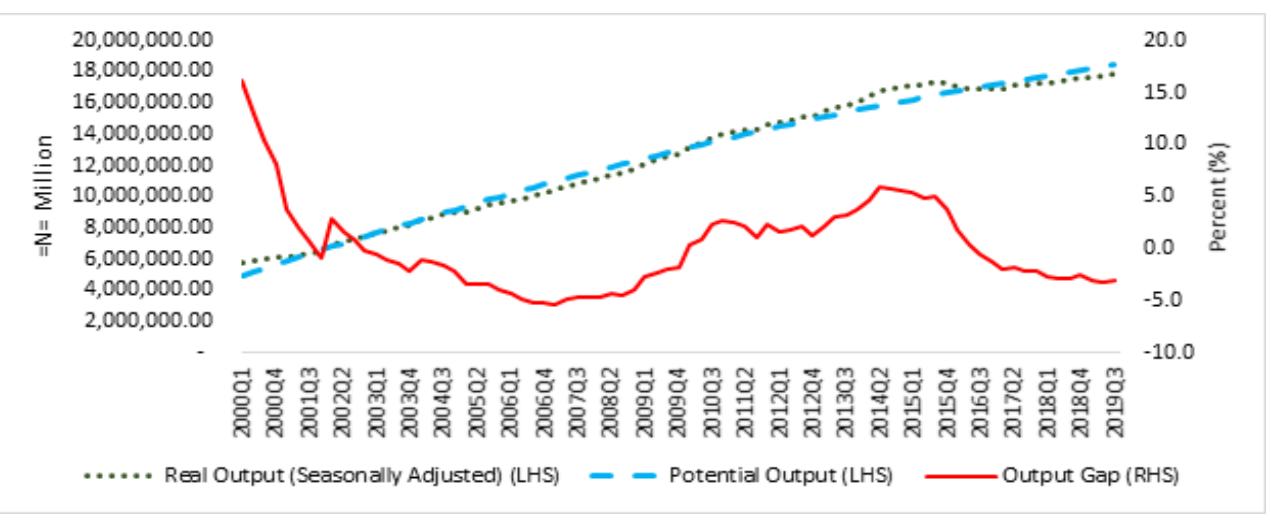

Figure 5: Nigeria's Output Gap

Source; Author's Computation

\section{Data and Methodology}

\subsection{Data}

This study used quarterly time series data spanning the period Q1:2000 to Q4:2018. The data were obtained from the Central Bank of Nigeria (CBN) Statistical Bulletin, the National Bureau of Statistics (NBS), Office of the Accountant General of the Federation (OAGF) and the Debt Management Office (DMO). The variables include government expenditure, tax revenue, primary balance, debts and debt service, debt to GDP ratio, expenditure to GDP, output gap as it affects the overall economic performance. We transformed most of the variables into ratios for uniformity. Our output gap variable was computed as the percentage difference between actual GDP and potential GDP computed using the E-views HP filter.

\subsection{Model Specification}

In line with Bohn (1998) on equation (2), we consider some variables that determine government primary balance. The variables include: revenue and debt to GDP ratio, output gap and 
interest rate and can be expressed as a functional equation:

$$
P B Y=f(D G D P, Q G A P, L R Y, L R T, T B R)
$$

The estimable function is derived from equation (3) and expressed as:

$$
P B Y_{t}=\alpha_{o}+\alpha_{1} D G D P_{t}+\alpha_{2} Q G A P_{t}+\alpha_{3} L R Y_{t}+\alpha_{4} L R T_{t}+\alpha_{5} T B R_{t}+\mu_{t}
$$

Which is the long-run equilibrium relationship amongst the variables, while the coefficients represent the elasticity of the variables with respect to primary balance (See Table 1 for definition of variables).

\subsubsection{Autoregressive Distributed Lag (ARDL) Methodology}

The paper employed the Autoregressive Distributive Lag (ARDL) bound test approach developed by Pesaran, Shin and Smith (2001) on equation (4) to test the existence of cointegration of the variables.

The ARDL specification of equation (4) is thus given as follows:

$$
\begin{aligned}
\Delta P B Y_{t}= & \alpha_{0}+\sum_{i=1}^{n} \alpha_{1 i} \Delta P B Y_{t-i}+\sum_{i=0}^{n} \alpha_{2 i} \Delta D G D P_{t-i}+\sum_{i=0}^{n} \alpha_{3 i} \Delta D G a p_{t-i}+\sum_{i=0}^{n} \alpha_{4 i} \Delta L R Y_{t-i} \\
& +\sum_{i=0}^{n} \alpha_{5 i} \Delta L R T_{t-i}+\sum_{i=0}^{n} \alpha_{6 i} \Delta T B R_{t-i}+\beta_{1} P B Y_{t-1}+\beta_{2} D G D P_{t-1}+\beta_{3} D G a p_{t-1} \\
& +\beta_{4} L R Y_{t-1}+\beta_{5} L R T_{t-1}+\beta_{6} T B R_{t-1}+\mu_{t}
\end{aligned}
$$

Where $\alpha_{0}$ represents the intercept, $\beta_{1}$ to $\beta_{6}$ are the long run multipliers; and $\mu_{t}$ is the error term. The equation is implemented with logged data.

Following Pesaran, Shina and Smith (2001), the decision criteria for establishing a long run relationship is based on an F-test of joint significance of the coefficients of the variables. The F-test is usually a test of hypothesis where the null represents no cointegration among variables and alternative indicates the existence of cointegration. If the F-statistic is greater than the upper bound, the alternative hypothesis is accepted. Conversely, the null hypothesis of no cointegration is accepted if the F-Statistics is below the lower bound and the result is deemed inconclusive if the F-statistics lies between the upper and lower bounds. The econometric details can be found in Pesaran et al. (2001). 
When long-run cointegration is established, then the error correction model is estimated to obtain the short run dynamics and long run adjustment parameter. The error correction model is specified as:

$$
\begin{aligned}
\Delta P B Y_{t}= & \alpha_{0}+\sum_{i=1}^{n} \alpha_{1 i} \Delta P B Y_{t-i}+\sum_{i=0}^{n} \alpha_{2 i} \Delta D G D P_{t-i}+\sum_{i=0}^{n} \alpha_{3 i} \Delta D G a p_{t-i}+\sum_{i=0}^{n} \alpha_{4 i} \Delta L R Y_{t-i} \\
& +\sum_{i=0}^{n} \alpha_{5 i} \Delta L R T_{t-i}+\sum_{i=0}^{n} \alpha_{6 i} \Delta T B R_{t-i}+\theta E C M_{t-1}+e_{t}
\end{aligned}
$$

Where $\Delta$ denotes the first difference operator. $\alpha_{0}$ represents the intercept and $\alpha_{1}$ to $\alpha_{6}$ are short run dynamic coefficients of the model, while $\theta$ is the rate of adjustment to equilibrium.

\begin{tabular}{|c|c|c|c|}
\hline Variables & Variable Notation & Measurement & A priori expectation \\
\hline Debt-GDP & DGDP & Ratio & -ve or + ve \\
\hline Output gap & QGAP & Absolute & $+\mathrm{ve}$ \\
\hline $\begin{array}{l}\text { Lagged revenue to } \\
\text { GDP }\end{array}$ & LRY & Ratio & $+\mathrm{ve}$ \\
\hline $\begin{array}{l}\text { Primary Balance to } \\
\text { GDP }\end{array}$ & PBY & Ratio & -ve or +ve \\
\hline T-bills Rate & TBR & percentage & -ve or ve \\
\hline Lending Rate & LRT & Percentage & $+\mathrm{ve}$ \\
\hline
\end{tabular}

Table 1: Variables Used in the Model and A Priori Expectations

For fiscal policy to be sustainable, we expect a positive relationship between debt and primary balance (Bohn, 1998). The debt to GDP ratio is expected to have a positive relationship with primary balance. Implying that, the government needs to respond to increasing levels of debt by building up primary surplus or reducing deficit. On the other hand, if a negative relationship exists between the variables, it can be explained that, government could not address the issues of debt accumulation and fiscal policy is not sustainable in the long run.

In addition, the apriori expectation of the coefficient of primary balance to GDP ratio is similarly positive or negative; this is based on interactions of the determinant of the primary balance. The output gap is expected to be positive. The economy is hence prone to shocks if output gap is negative. Uncertainty about the size of the output and hence its impact on fiscal outcome has increased since the 2007/2008 global financial crisis. The concerns will continue due to the high level of debt.

Revenue plays an important role in determining a country's primary balance. If government revenue increases in a fiscal year, the country's fiscal deficit may reduce for that cyclical 
period. Thus, the need for the country to borrow would be minimised thereby improving the primary balance. Interest payments on financial instruments by government is proxied by Treasury Bill Rates; and is expected to be positive; if government interest payments on debt instruments increases, it adds to the level of the country's debt services payment (deficit primary balance) and vise-versa.

\section{Results and Discussion}

\subsection{Unit Roots Tests}

The Augmented Dickey Fuller (ADF) and the Philip Peron (PP) tests statistics with both intercept and trend, were used for establishing the existence or otherwise of unit roots. We compared the 't' values with the Mackinnon critical values to reject or not, the hypothesis that a unit root exists. On the back of conventional approach, we choose 5 per cent as our critical value. The tests results are shown in Table 2. The hypothesis is formulated thus:

Ho: $\theta=1$ (Non-stationary)

H1: $\theta<1$ (stationary).

Table 2: Unit Root Test - Augmented Dickey-Fuller (ADF) and Philips-Perron (P-P)

\begin{tabular}{lllllll}
\hline Variables & $\begin{array}{l}\text { ADF } \\
\text { Level }\end{array}$ & $\begin{array}{l}\text { First } \\
\text { Diff. }\end{array}$ & $\begin{array}{l}\text { Order of In- } \\
\text { tegration }\end{array}$ & $\begin{array}{l}\text { P-P } \\
\text { Level }\end{array}$ & $\begin{array}{l}\text { First } \\
\text { Diff. }\end{array}$ & $\begin{array}{l}\text { Order of In- } \\
\text { tegration }\end{array}$ \\
\hline $\mathrm{D}(\mathrm{PBY})$ & $0.0000^{* *}$ & $0.0000^{* *}$ & $\mathrm{I}(1)$ & $0.0000^{* *}$ & $0.0001^{* *}$ & $\mathrm{I}(1)$ \\
$\mathrm{D}(\mathrm{TBR})$ & $0.0102^{* *}$ & $0.0000^{* *}$ & $\mathrm{I}(1)$ & $0.0019^{* *}$ & $0.0000^{* *}$ & $\mathrm{I}(1)$ \\
$\mathrm{D}(\mathrm{QGAP})$ & $0.0114^{* *}$ & $0.0028^{* *}$ & $\mathrm{I}(1)$ & $0.0002^{* *}$ & $0.0001^{* *}$ & $\mathrm{I}(1)$ \\
$\mathrm{D}(\mathrm{LRT})$ & 0.7139 & $0.0000^{* *}$ & $\mathrm{I}(1)$ & 0.7010 & $0.0000^{* *}$ & $\mathrm{I}(1)$ \\
$\mathrm{D}(\mathrm{LRY})$ & 0.2012 & $0.0000^{* *}$ & $\mathrm{I}(1)$ & $0.0287^{* *}$ & $0.0001^{* *}$ & $\mathrm{I}(0)$ \\
$\mathrm{D}(\mathrm{DGDP})$ & 0.5350 & $0.0000^{* *}$ & $\mathrm{I}(0)$ & 0.5533 & $0.0000^{* *}$ & $\mathrm{I}(0)$ \\
\hline Note: ${ }^{* *}$ Significant at $5 \%$ level & & & & \\
\hline
\end{tabular}

The ADF and the PP stationarity result tests in Table 2 reveal that some variables were stationary at levels $\mathrm{I}(0)$ and first difference $\mathrm{I}(1)$; thus validating the use of the ARDL (bounds Test)

\subsection{Bounds Tests for Cointegration}

We adopted the Bound Test (ARDL) to show whether cointegration relationship exist among the variables that determine the primary balance. After the order of integration has been established, we then tested for the long run relationship between the variables using the bounds test. The ARDL model was also used to confirm the result of the coin-integration 
test. The variables include ratio of primary balance to GDP (PBY), Interest payments on debt (proxied by TBR), output gap, (QGAP), lending rate (LRT), ratio of lagged revenue to GDP (LRQ), and ratio of debt to GDP (DGDP. From Table 3, the result of the bounds test demonstrates a strong evidence of a long-run relationship between the variables when compared with the Pesaran et al (2001) critical value at the lower and upper bounds. The F-statistic in the model is greater than both the lower and the upper bounds critical value, hence the conclusion that there exists long-run relationship between the primary balance to GDP ratio and its determinants. Subsequently, our equation is estimated using the ARDL co-integration technique for long run estimates.

Table 3: Results of Wald Test

\begin{tabular}{lllll}
\hline Test Statistic & Value & Significance & $\mathrm{I}(0)$ & $\mathrm{I}(1)$ \\
\hline F-statistic & 10.37 & $10 \%$ & 2.08 & 3.00 \\
$\mathrm{k}$ & 5 & $5 \%$ & 2.39 & 3.38 \\
& & $2.5 \%$ & 2.7 & 3.73 \\
& & $1 \%$ & 3.06 & 4.15 \\
\hline
\end{tabular}

\subsection{Results of Long-Run Regression Estimates}

From the ARDL estimation result presented in Table 4, the coefficient of public debt to GDP $(\mathrm{DGDP})$, which is the major determinant of primary balance (PBY), showed a negative sign (-0.0201) and statistically significant, implying that, a fiscal rule that encourages a strong reduction in debt-to-GDP levels would result in substantial pressure for Nigeria to run large primary surpluses in the long-run or future. A negative relationship implies that, government is not able to adjust its fiscal policy in response to the country's debt accumulation. This result confirms the persistence of fiscal deficit in Nigeria in the absence of buffers. Thus, In addition, the significant sign shown by the coefficient of public debt to GDP, suggests that Nigeria's debt burden has been persistence over the years and current fiscal policy measures are not sustainable in the long-run. Thus, an increase in the debt-to-GDP ratio could worsen the overall primary balance, i.e. negative primary balance if there are deliberate policies to increase the primary surplus. Our results confirm studies by Adeosun and Adedokun (2019) who found a negative response of government primary balances to changes in public debt and the other by Otonne, and Oyenuga (2019) which found that, government borrowing, and fiscal policies are not sustainable. However, recent Debt Sustainability Analysis (DSA) for Nigeria by the Debt Management Office (DMO, 2018) supports the claim that Nigeria still have the capacity to increase its borrowing and remain within the threshold. 
On the effectiveness of revenue collection on primary balance, proxied by lag of revenue to GDP ratio (LRY), the result shows a positive but statistically insignificant relationship, indicating that government revenue did not contribute to the primary balance during the review period. Deficit gap reduces, if government revenue increases through increased tax and revenue from oil and other non-oil receipts, hence improving the primary deficit and vis-visa. The coefficient of the output gap though positive, was not statistically significant at the 5 per cent level. The result is in conformity with our apriori expectation. This implies that, improvements in national output would improve the fiscal sustainability position in Nigeria. However, a plausible explanation of the insignificance of the output gap variable is because the revenue base of the Nigerian economy is not diversified as oil sector/ revenue which accounts for over 90 per cent of government revenue, accounts for only less than 15 per cent of overall GDP.

Table 4: Estimated Long-Run Coefficients ARDL (3,2,0,1,2,2)

Dependent Variable: D(PBY)

Selected Model: ARDL $(3,2,0,1,2,2$,

\begin{tabular}{lllll}
\hline Variables & Coefficient & Std. Error & t-Statistics & $p$-Values \\
\hline DGDP & -0.0201 & 0.0046 & -4.3810 & 0.0001 \\
LRY & 0.0544 & 0.0610 & 0.8916 & 0.3763 \\
QGAP & 0.0000 & 0.0000 & 1.9131 & 0.0608 \\
TBR & 0.0011 & 0.0005 & 2.2395 & 0.0290 \\
LRT & 0.0002 & 0.0006 & 0.2686 & 0.7892 \\
C & -0.0338 & 0.0147 & -2.2949 & 0.0254 \\
\hline
\end{tabular}

Source: Authors' Computation

The TBR rate which proxies the cost of government borrowings has a positive and significant coefficient. The result conforms with our apriori expectations. High T-bill rates discourage government borrowing from that particular source, thus reducing the level of government debts, and improving the primary balance position (primary surplus). Equally, the debt instrument can also increase government debt services, thus worsening the primary balance position. The lending rate is expected to be above the inflation rate, similarly, high lending rates discourages government's borrowings, while, low lending rates attracts more borrowing from the government and the public. From our result, the positive coefficient shown by lending rate (LRT) is in tandem with our a priori expectation. It implies that, a rise in lending rate indicates increased borrowing cost and will result to increased fiscal deficit of government because higher lending exposure increases risk-taking substantially. Theoreti- 
cally, increased levels of government borrowing can lead to 'crowding out'. However, the coefficient of domestic lending rate (LRT) is statistically insignificant. This is counterintuitive since the government does not borrow directly from the deposit money banks. There is also the possibility that the overall effect of a strong credit supply shock on the primary balance of government attenuated during the review period.

Our measure of the fiscal reaction function (PBY) which is the ratio of primary balance to GDP could be positive (primary surplus) or negative (primary deficit). The result from our estimation states that, the coefficient of debt to GDP ratio is negative and statistically significant; indicating that government fiscal policy stance has not been responsive to changes in its debt level. Every government aims to minimize its primary balance position, however due to some imbalances in the economy, most countries experience budgetary deficits. We therefore conclude that fiscal policy stance in Nigeria is not sustainable in the long-run.

Meanwhile the F-statistic figure in the bounds test reflects the long-run relationship among variables based on whether it is greater or lower that the threshold. The result in Table 4 shows that the F-Statistics (10.37) is greater than the lower and upper bounds showing the overall significance of the model in both short and the long-run and indicating a long-run relationship among the variables even at $1 \%$ level.

\subsection{ARDL Error Correction Regression}

The short-run dynamic parameters were obtained by estimating an error correction model associated with the long-run estimates. The ARDL Error Correction Regression result in Table 5 showed the coefficient of the ECM to be -1.75 . This is negative and highly significant at 1 per cent. The coefficient is consistent and fulfils the condition of the error correction term. The error correction term represents the speed of adjustment from the initial level of disequilibrium to a long-term equilibrium path. This imply that, the disequilibrium of primary balance to GDP (PBY) resulting from a shock in the preceding quarter, would be corrected by 175 per cent in the following quarter to attain equilibrium level in the long run. Theoretically, the error correction term (ECT) should lie between -1 and 0 . Consequently, the -1.75 simply means that the convergence or error correction mechanism is oscillatory in which case fiscal policy actions may take a much shorter time to achieve steady state. In other words, the speed of adjustment fluctuates forward before settling to equilibrium. Our result could be explained by the level of shock absorption/adjustment and the flexibility of 
the Nigerian economy.

The study by Olanrewaju et.al (2012) using ARDL approach showed similar outcome with an ECT coefficient of minus 1.21. Narayan and Smyth (2006) also estimated short-run coefficients using the ARDL approach and had an ECT of 1.21 in their study. They explained that, the error correction process is achieved in decreasingly fluctuating form. In their view, the ECM fluctuates around the long-run value in a dampening manner instead of monotonically converging to the equilibrium path directly. Thus, the convergence to the equilibrium path becomes rapid once this process is complete. In our case, the ECM -1.75 may not be unconnected with the frequency of the data used as well as outliers especially as it relates to fiscal data in most developing economies. For example, Nigeria's debt to GDP ratio has been rising on a regular basis and the quality of the fiscal data and how each element in the computation of the public debt-GDP is tracked will affect the determination of the ECT. The variables that are significant at 5 percent in the ECM are primary balance to GDP (DPBY), T-bill rate (DTBR), debt to GDP ratio (DGDP) and lending rate (DLRT). Like the long run model, the coefficient of the output gap (DQAP) was again, not statistically significant at the 5 per cent level.

Table 5: Error Correction Estimates of the ARDL Model

Dependent Variable: D(PBY)

\begin{tabular}{lllll}
\hline Regressors & Coefficient & Std. Error & t-Statistics & $p$-Values \\
\hline D(PBY(-1)) & 0.5559 & 0.1445 & 3.8471 & 0.0003 \\
D(PBY(-2)) & 0.3749 & 0.0955 & 3.9246 & 0.0002 \\
D(DGDP) & -0.0991 & 0.0299 & -3.3107 & 0.0016 \\
D(DGDP(-1)) & 0.0810 & 0.0244 & 3.3131 & 0.0016 \\
D(QGAP) & 0.0000 & 0.0000 & -0.1790 & 0.8585 \\
D(TBR) & 0.0001 & 0.0011 & 0.0877 & 0.9304 \\
D(TBR(-1)) & -0.0023 & 0.0011 & -1.9820 & 0.0523 \\
D(LRT) & -0.0059 & 0.0022 & -2.6138 & 0.0114 \\
D(LRT(-1)) & 0.0041 & 0.0025 & 1.6286 & 0.1089 \\
CointEq (-1)* & -1.7520 & 0.1956 & -8.9591 & 0.0000 \\
$R^{2}=0.73$ & Durbin-Watson=1.90 & & \\
Adjusted R ${ }^{2}=0.69$ & AIC $=4.80$ & SIC $=4.48$ & $\mathrm{HQC}=4.67$ \\
\hline Source $:$ Authors' Computation
\end{tabular}

Source: Authors' Computation

From our results, the fiscal response becomes more crucial especially if the shock tends to produce negative outcomes. For instance, oil receipts constitute the most integral part of government revenue in Nigeria. Thus, an adverse oil price shock or production cut, can 
impact negatively on government's fiscal revenue and the performance of the budget. It follows therefore that, if fiscal policy action is very sluggish, the negative oil price shock will persist for a very long time, as well as the potential adverse consequences that it will create. In such circumstances, fiscal policy may not be growth-enhancing, and this may require the intervention of the fiscal authorities towards developing the domestic market to support growth particularly in the non-oil sectors in order to diversify the revenue base of the economy. To achieve this objective, the government could give incentives to sectors that are driving growth in the economy or provide subsidies to other sectors of the economy that are very vulnerable.

In addition, we have been able to achieve a major objective of the paper which is to evaluate and ascertain if a long-term relationship exists between the Primary Balance and Debt to GDP Ratio with the aid of ARDL approach. This has been achieved with the results from the Bounds Test. The diagnostic and stability tests carried out affirmed the stability of the model, no serial correlation problem and the model was adjudged to be homoscedastic.

\subsection{Model Diagnostic Test}

\subsubsection{Normality Test}

The result of the Normality test (Figure 6) showed that the Jarque-Bera test statistics is 0.23 which is greater than 5 per cent (0.05). This indicates that the residuals are normally distributed. In addition, the Kurtosis is 2.77 which is within the acceptable range of -3 and +3 .

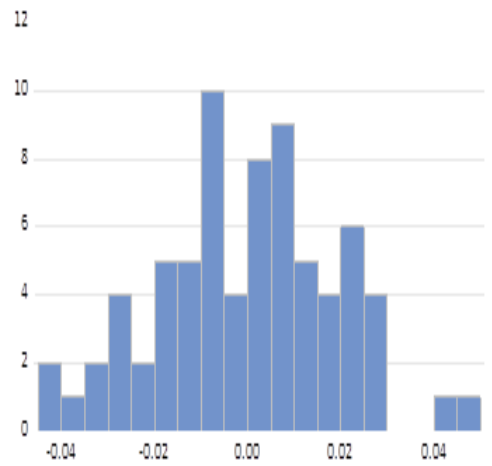

Figure 6: Normality Test

\begin{tabular}{lr}
\hline Series: & Residuals \\
Sample: & 476 \\
Observations: & 73 \\
\hline & \\
Mean: & $-3.18 \mathrm{E}-17$ \\
Median: & 0.002168 \\
Maximum: & 0.047694 \\
Minimum: & -0.044732 \\
Std. Dev. & 0.019244 \\
Kurtosis: & 2.767360 \\
& \\
Jarque-Bera & 0.236891 \\
Probability: & 0.888300 \\
\hline
\end{tabular}




\subsubsection{Model Stability Test}

In order to incorporate the short-run dynamics for consistency of long-run parameters, we used the stability of long-run coefficients as a basis for the error-correction term. We thus applied the CUSUM and CUSUMSQ tests developed by Brown et al (1975). From the plots of the CUSUM and CUSUMSQ, the statistics are within the critical 5 per cent critical bounds implying that the coefficient of the model is stable.

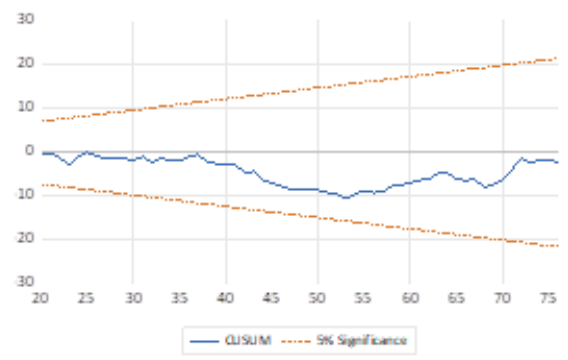

Figure 7a: CUSUM

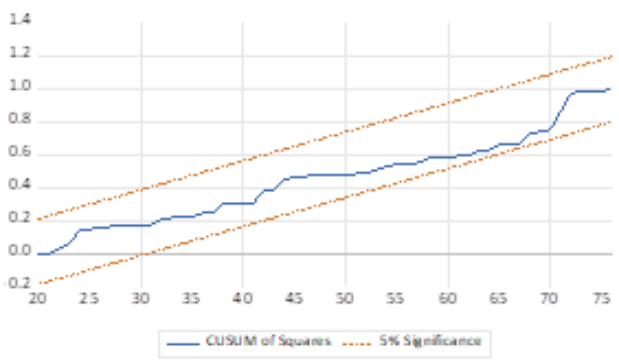

Figure 7b: CUSUMSQ

The result below shows that the model is devoid of autocorrelations as the F-statistics is not significant at 0.57 , the null is rejected.

\subsubsection{Residual Diagnostic Test}

Table 6: Breusch-Godfrey Serial Correlation LM Test

\begin{tabular}{llll}
\hline F-statistic & 0.564957 & Prob. F(2,55) & 0.5716 \\
Obs*R-squared & 1.469514 & Prob. Chi-Square (2) & 0.4796 \\
\hline
\end{tabular}

Table 7: Heteroskedasticity Test: Breusch-Pagan-Godfrey

\begin{tabular}{llll}
\hline F-statistic & 1.079083 & Prob. F(15,57) & 0.3953 \\
Obs*R-squared & 16.14506 & Prob. Chi-Square (22) & 0.3725 \\
Scaled explained SS & 8.698384 & Prob. Chi-Square (22) & 0.8928 \\
\hline
\end{tabular}

\subsection{Sensitivity Analysis}

Given the revealed over-correction of the estimated model, as the ECM is 1.75, the paper further tested the sensitivity of the model to structural break. This is with the intuition that accounting for structural breaks could moderate the oscillating behavior of the model. The Bai-Perron (2003) multiple Breakpoint approach showed evidence of structural breaks in the model, suggesting that the model could be sensitive to structural break. The analysis of the result showed a structural change in the lagged revenue to GDP (LRY) in 2010: Q1 (Table 
8). On the basis of this, we re-estimated the ARDL model while accounting for the identified break with a dummy variable (DUMSB).

From Table 9, cointegration of the variables was established in the presence of structural change as the value of F-Statistic (13.06) lies above the upper bound (2.94), which gives credence for the estimation of the long run ARDL model.

Table 8: Bai-Perron Breakpoint Tests

Sequential F-statistic determined breaks:

\section{1}

\begin{tabular}{|c|c|c|c|}
\hline Break Test & F-statistic & $\begin{array}{l}\text { Scaled } \\
\text { F-statistic }\end{array}$ & $\begin{array}{l}\text { Critical } \\
\text { Value** }\end{array}$ \\
\hline 0 vs. $1 *$ & 180.1632 & 180.1632 & 8.5800 \\
\hline 1 vs. 2 & 3.5276 & 3.5276 & 10.1300 \\
\hline \multicolumn{4}{|c|}{ * Significant at the 0.05 level. } \\
\hline \multicolumn{4}{|c|}{$\begin{array}{l}\text { ** Bai-Perron (Econometric Journal, 2003) critical values. } \\
\text { Break dates: }\end{array}$} \\
\hline & Sequential & Repartition & \\
\hline 1 & 2010Q1 & 2010Q1 & \\
\hline
\end{tabular}

Table 9: Results of Long-Run Bounds Test

\begin{tabular}{lllll}
\hline Test Statistic & Value & Signif. & $\mathrm{I}(0)$ & $\mathrm{I}(1)$ \\
\hline F-statistic & 13.06 & $10 \%$ & 1.99 & 2.94 \\
$\mathrm{k}$ & 6 & $5 \%$ & 2.27 & 3.28 \\
& & $2.5 \%$ & 2.55 & 3.61 \\
& & $1 \%$ & 2.88 & 3.99 \\
\hline
\end{tabular}

Null Hypothesis: No levels relationship

From the ARDL estimation in Table 10, the coefficient of public debt to GDP (DGDP), which is the major determinant of primary balance (PBY), showed a negative sign (-0.123) and was statistically insignificant, implying that, a fiscal rule that encourages a strong reduction in debt-to-GDP levels would lead to a decrease in the future primary deficit of government because an increase in debt stock increases the overall primary deficit, i.e. negative primary balance. A negative relationship implies that, government is not able to adjust its fiscal policy in response to the country's debt accumulation. This result confirms the persistence of fiscal deficit in Nigeria in the absence of buffers. The output gap variable (QGAP) was statistically significant and positive. 
Table 10: ARDL Long-run Bound Test with Structural Break

Dependent Variable: D(PBY): Selected Model: ARDL $(3,2,0,1,2,2$,

\begin{tabular}{lllll}
\hline Variables & Coefficient & Std. Error & t-Statistics & $p$-Values \\
\hline LRY & -0.2408 & 0.1793 & -1.3434 & 0.1844 \\
LRT & 0.0004 & 0.0011 & 0.3785 & 0.7065 \\
DUMSB & -0.0241 & 0.0157 & -1.5371 & 0.1297 \\
DGDP & -0.0124 & 0.0078 & -1.5922 & 0.1168 \\
QGAP & 0.0000 & 0.0000 & 2.7447 & 0.0080 \\
TBR & -0.0002 & 0.0008 & -0.2400 & 0.8112 \\
C & -0.0003 & 0.0272 & -0.0115 & 0.9909 \\
Source: Authors' Computation & & &
\end{tabular}

The parameters of the short-run model were obtained by estimating an error correction model with structural breaks. The ARDL Error Correction Regression showed a lower coefficient of the ECM to be -1.11. This is negative and highly significant at 1 per cent, further suggesting the sensitivity of the structural change in the behavior of the fiscal reaction function. The coefficient is consistent with the apriori expectation of error correction term implying that, disequilibrium of primary balance to GDP (PBY) resulting from a shock in the preceding quarter, would be fully corrected in the following quarter.

Table 11: ARDL Error Correction Regression with Structural Break Dependent Variable: D(PBY)

\begin{tabular}{lllll}
\hline Regressors & Coefficient & Std. Error & t-Statistics & $p$-Values \\
\hline $\mathrm{D}($ LRY) & -0.0399 & 0.0912 & -0.4378 & 0.6632 \\
$\mathrm{D}($ LRT $)$ & -0.0026 & 0.0023 & -1.1306 & 0.2629 \\
$\mathrm{D}($ LRT(-1)) & 0.0061 & 0.0025 & 2.4054 & 0.0194 \\
$\mathrm{D}($ LRT(-2)) & 0.0061 & 0.0026 & 2.3581 & 0.0218 \\
$\mathrm{D}(\mathrm{DGDP})$ & -0.0715 & 0.0309 & -2.3164 & 0.0241 \\
$\mathrm{D}(\mathrm{DGDP}(-1))$ & 0.0689 & 0.0272 & 2.5387 & 0.0138 \\
$\mathrm{D}(\mathrm{QGAP})$ & 0.0000 & 0.0000 & 1.3531 & 0.1813 \\
CointEq(-1)* & -1.1143 & 0.1030 & -10.8221 & 0.0000 \\
$\mathrm{R}^{2}=0.70$ & Durbin-Watson $=2.17$ \\
Adjusted R $\mathrm{R}^{2}=0.67 \quad$ AIC $=(4.75)$ & SIC $=(4.50)$ & $\mathrm{HQC}=(4.667)$ \\
Source: Authors' Computation
\end{tabular}

\subsection{Conclusion and Policy Recommendation}

In this paper we estimated a fiscal reaction function for the Nigerian economy and the impact of the selected macroeconomic variables on the primary balance of government. The paper focused on the period which accompanied the transition to civil democracy to the last quarter of 2018 (2000:Q1 to 2018:Q4). Our objective was to estimate the fiscal reaction function for Nigeria and determine whether the implementation of fiscal policy in Nigeria is sustainable 
in the long-run. The analysis of the stylized facts reveals that, except for a few short periods, the government had continued to run budget deficits for almost the entire period that the study covered. The study employed ARDL (Bounds Test) to establish the relationships and interactions among the variables of interestr. The study investigated whether the fiscal measures pursued by the government during the review period was adequate in addressing the accumulation of huge debt. The analysis of the stylized facts reveals that, except for a few short periods, the government had continued to run budget deficits for almost the entire period that the study covered 2000:Q1 to 2018:Q4. The government tended to run deficits even during the period of high oil prices and favorable macroeconomic environment. The deficits also coincided with high GDP growth. The periods, especially from mid-2014 witnessed the collapse of oil prices, leading to declining growth and culminating into economic recession. The low oil prices manifested in low receipts and as expected and elevated the deficits.

Our study derived the path of the public debt to GDP and primary balance based on a fiscal rule calibrated to an estimated Fiscal Reaction Function (FRF) for Nigeria that demonstrates the budgetary constraint faced by government. The ARDL model employed showed that the long-run coefficient of public debt to GDP which is a major determinant of the primary balance, is negative and significant implying that a fiscal rule that encourages a strong reduction in debt-to-GDP levels would result in substantial pressure for Nigeria to run large primary surpluses in the future. A negative relationship implies that, government is not able to adjust its current fiscal policy in response to the country's debt accumulation. The findings confirm the persistence of fiscal deficit in Nigeria in the absence of buffers. By principle, the government is expected to respond through measures that would improve the primary balance position, to stem debt increase. An increase in total debt, causes reduction or could worsen the future primary balance of government implying that, the current public debt stock could have severe impact on primary balances in the long run. If, the public debt/GDP ratio increases, the government is by principle, expected to respond through measures that would improve the primary balance, to stem the increase.

From the results also, the lag of revenue to GDP ratio showed a positive significant relationship on primary balance implying that the government primary balance increases (primary surplus) as revenue of government increase. The positive coefficient shown by the output gap variable is statistically insignificant at 5 per cent level, this also conforms to our a priori 
expectation pointing to a counter-cyclical policy.

To account for the behaviour of the ECM, which was earlier estimated at 1.75 , we further tested the sensitivity of the model by re-estimating our error correction model in the presence of structural breaks. The objective was to moderate the oscillating behavior of the model. The Bai-Perron Multiple Breakpoint approach showed evidence of structural breaks in the variables around 2010:Q1. We thereafter introduced a dummy variable to capture the structural break. The re-estimated ARDL Error Correction term showed, however, a lower coefficient of the ECM of -1.11 , even after accounting for structural breaks. This is highly significant and negative at 1 percent.

Overall, the coefficient of primary balance to GDP represents the Fiscal Reaction Function (FRF), which is negative (-0.0338) implying that the fiscal policy measures in the period under review, have not shown enough response to the country's increasing debt levels, and thus, not sustainable in the longrun. Every country strives to achieve primary balances surplus, but this may sometimes be unachievable due to some imbalances in the economy, particularly low revenue receipts, which could result to accumulated borrowings.

Based on the findings of this study, we recommend as follows: that, going forward, fiscal consolidation would be required to reduce the size of the debt and return the debt stock to a declining trajectory and at sustainable levels. Our results confirmed that, the country's debt stock is significant and represents a major determinant of the primary balance. The fiscal authority should therefore, base its borrowing within agreed thresholds (the debt-toGDP ratio or revenue- to-GDP ratio). This is usually based on the Federal Government's Public Debt Sustainability Framework (DSF). This is in addition to achieving the level of primary surplus required for stabilizing debt over a given period. The level chosen should be consistent with output in view of the need to formulate a fiscal rule that allows the primary balance to automatically adjusts to the output gap and to the public debt. The authorities should support additional reforms that are geared towards encouraging increased savings and overall fiscal sustainability. In this regard, the government should strengthen current efforts at economic diversification. The policy should be complemented by a more efficient tax collection process, improved non-oil revenue collections; and implementation of further reforms to ensure overall fiscal sustainability. Finally, apart from the urgent need for the fiscal authorities to adopt urgent reforms to discourage huge debt accumulation, improve revenue 
generation capacity and more fundamentally, expenditure switching to improve the quality and efficiency of expenditure, the transition from primary deficits to primary surpluses should follow a gradual process.

\section{References}

Ariyo, A. (1993). An Assessment of the Sustainability of Nigeria's Fiscal Deficit: 1970-90. Journal of African Economies, 2 (2), 262-282.

Bohn, H. (1998). The Behavior of US Public Debt and Deficits. The Quarterly Journal of Economics, 113(3), 949-963.

Adedeji, O. S. \& Williams, O. (2006). Fiscal Reaction Functions in the CFA Zone: An Analytical Perspective. International Monetary Fund (IMF) Working Paper No. WP/07/232

Adeosun, O.A. \& Adedokun, S. A. (2019) Fiscal Reaction Functions and Public Debt Sustainability in Nigeria: An Error Correction Mechanism Approach. International Journal of Public Policy and Administration Research. Conscientia Beam, 6(2), 116-132.

Ariyo, A. (1993). An Assessment of the Sustainability of Nigeria's Fiscal Deficit: 1970-90. Journal of African Economies, 2(2), 262-282

Afonso, A \& Jalles, J.T (2011). Growth and Productivity: The Role of Government Debt, Working Papers. Department of Economics 2011/13, ISEG - Lisbon School of Economics and Management. Universidade de Lisboa.

Afonso, A. \& Jalles, J.T. (2015). Euro Area Time Varying Fiscal Sustainability. Working Papers. Department of Economics, Lisbon School of Economics and Management. WP13/2015/DE/UECE

Asiama, J., Akosah, N., \& Owusu-Afriyie, E. (2014). Assessment of Fiscal Sustainability in Ghana. Bank of Ghana, Working Paper WP/BOG-2014/09

Baunsgaard, T. (2019). Fiscal Policy in Nigeria: Any Role for Rules?. IMF Working Paper, $W P / 03 / 155$

Blanchard, O., Chouraqui, J.-C., Hagemann, R. \& Sartor, N. (1990). The Sustainability of Fiscal Policy: New Answers to an Old Question. OECD Economic Studies, 15, 7-36.

Burger, P., et al. (2011). Fiscal Sustainability and the Fiscal Reaction Function for South Africa. IMF Working Paper Series. WP11/69

Bohn, H. (1998). The Behavior of US Public Debt and Deficits. The Quarterly Journal of Economics, 113(3), 949-963.

Bohn, H. (2007). Are Stationary and Cointegration Restrictions Really Necessary for Intertemporal Budget Constraint? Journal of Monetary Economics, 54(7), 1837-1847. 
Brown, R. L., Durbin, J. \& Evans, J. M. (1975). Techniques for Testing the Constancy of Regression Relationships over Time. Journal of the Royal Statistical Society. 37(2), 149-192.

Checherita-Westphal, C. \& Václav Ždárek, V. (2017). Fiscal Reaction Function and Fiscal Fatigue: Evidence for the Euro Area. European Central Bank. Working Paper Series, No. 2036. March.

Debt Management Office (2018). Nigeria Debt Profile. www.dmo.gov.ng

De Mello, L. R. (2005). Globalization and Fiscal Federalism: Does Openness Constrain Subnational Budget Imbalances? Public Budgeting and Finance. 25(1), 1-14. Wiley Online Library.

Gali, J. \& Perotti, R. (2003). Fiscal Policy and Monetary Integration in Europe. Economic Policy. 18 (37), 533 - 572.

Ganyaupfu, E. M. (2014). Fiscal Sustainability in South Africa: Recent Evidence. Journal of Social Economics. 1(4), 2014, 159-167

Halland, H. \& Bleany, M. (2009a). The Resource Curse and Fiscal Policy Volatility. Credit Research Paper. No. 09/09.

Halland, H \& Bleany, M. (2009b). Explaining the Procyclicality of Fiscal Policy in Developing Countries. Credit Research Paper. No. 11/09.

Hodrick, R.J \& Prescott, E.C. (1997). 'Postwar U.S. Business Cycles: An Empirical Investigation".Journal of Money, Credit, and Banking. Volume 29(1), 1-16.

Hodrick, R.J (2020). An Exploration of Trend-Cycle Decomposition Methodologies in Simulated Data. National Bureau of Economic Research. Working Paper 26750. Cambridge, MA 02138

Mello, Luiz de (2007). Estimating a Fiscal Reaction Function: The Case of Debt Sustainability in Brazil, Applied Economics, 40(3), 271-84.

Mutuku, C. (2015). Assessing Fiscal Policy Cyclicality and Sustainability: A Fiscal Reaction Function for Kenya. Journal of Economics Library www.kspjournals.org 2(3). September

Muzenda, A. (2014) An Empirical Assessment of Fiscal Sustainability in South Africa. Journal of Economics and Sustainable Development. 5(23), www.iiste.org ISSN 22221700 (Paper) ISSN 2222-2855 (Online).

Narayan, P.K \& Smyth, R. (2006). "What Determines Migration Flows from Low-Income to High-Income Countries? An empirical Investigation of Fiji-US Migration 19722001.Contemporary Economic Policy 24(2), 332-342 
Nguyen, T. (2013). Estimating India's Fiscal Reaction Function, ASARC Working Papers 2013-05, The Australian National University, Australia South Asia Research Centre.

Office of the Accountant General of the Federation (OAGF) (2018). Audit Reports and Publications. www.oafg.gov.ng

Okoye, L. U., Omankhanlen, A. E., Okorie, U. E., Okoh, J. I. \& Ahmed, A. (2019). Persistence of Fiscal Deficits in Nigeria: Examining the Issues. Investment Management and Financial Innovations, 16(4).

Olanrewaju I. S., Raphael A.Y, \& OlaOluwa S.Y (2012) On Autoregressive Distributed Lag, Cointegration and Error Correction Model (An Application to Some Nigeria Macroeconomic Variables) Australian Journal of Business and Management. 2(8).

Opeoluwa, A. A. \& Sikiru A. A. (2019). Fiscal Reaction Functions and Public Debt Sustainability in Nigeria: An Error Correction Mechanism Approach. International Journal of Public Policy and Administration. 6(2), 116-132.

Oronde, S., Leanora B. \& Gustavo, C. (2019). The Fiscal Policy Response to Public Debt in Developing Countries. Contemporary Economic Policy. 38(1), 155-165.

Otonne, A. \& Oyenuga, O. (2019). "How Sustainable is the Federal Government of Nigeria Debt after the Exit from Paris Club? African Journal of Economic Review 7(2).

Owolabi, A. U. \& Dauda, G. A. (2017). A Structural Break Analysis of Fiscal Deficit Process in Nigeria. The Review of Black Political Economy. 44, 341-352.

Oyekele, O. J. \& Ajilore, O. T. (2014). Analysis of Fiscal Deficit Sustainability in the Nigerian Economy: An Error Correction Approach. Asian Economic and Financial Review, 4(2), 199-210.

Pesaran, M. H., Shin,Y., \& Smith, R. J. (2001). Bounds Testing Approaches to the Analysis of Level Relationships. Journal of Applied Econometrics. 16(3), 289-326.

Sims, C.A. (1980). Macroeconomics and Reality. Econometrica, 48(1), 1-48.

Stoica, T. \& Leonte, A. (2011). Estimating a Fiscal Reaction Function for Greece. 2011 International Conference on Financial Management and Economics, IPEDR.11 (2011), IACSIT Press, Singapore.

Weichenrieder, A. \& Zimmer, J. (2014). Euro membership and Fiscal Reaction Functions. International Tax and Public Finance, 21(4), 598-613. 